\title{
Participants in Constitutional Process Before the Albanian Constitutional Court
}

\section{Erind Merkuri}

\author{
Lecture of the subject Constitutional Law, Department of Public Law, Faculty of law, University of Tirana Faculty of
} Law - University of Tirana; Email: erind.merkuri@fdut.edu.al

\section{Doi:10.5901/mjss.2015.v6n5p298}

\begin{abstract}
The constitutional process in its entirety, despite of the well-defined procedural rules, it can not be developed without the procedural parties. These are the parties who set in motion the constitutional court and therefore the whole procedural mechanism, with all its complexity. For this reason The Constitution of Albania and LCC define a set of procedural norms which aim to arrange the position and procedural rights of the parties in the constitutional process. Nevertheless parties tend either to abuse with the possibility to invest Constitutional Court (the applicant), or to require the limitation of the jurisdiction of this court in order not to take into consideration such matters (the concerned party). To avoid such situations and in addition to streamline the constitutional process within the legal norms and rules, the burned lies on the Constitutional Court, which in this case for a better progress of the constitutional process and also to respect the rights of the parties, legitimizes only those entities which have interest in participating in such a process as are well defined by the Constitution and the law. The purpose of this article is to give an overview on the procedural position of the parties involved in a constitutional trial.
\end{abstract}

Keywords: Constitutional process, applicant, interested parties, judicial position, direct interest.

Constitutional judgment is a contradictory judgment and as such it takes place between various parties, which CCL ${ }^{1}$ has named as the participants in the Constitutional Court. The first reference for the participants in the Constitutional Court is found in the wording that the letters "a" and "b" of Article 28.1 of $\mathrm{CCL}$, where it results that these parties are titled applicant and interested parties. Further into Article 39 of $\mathrm{CCL}$ is being provided a more complete picture about the meaning of the term "applicant" and "interested parties". Specifically, this provision has the following contents:

1. Participants in the Constitutional Court are:

a) The requesting entity who presented the request or its representative.

b) Entities against whom the request is being presented or who have a direct interest in the matter being considered.

c) The body that issued the act.

d) State organs that are in a disagreement about competency.

2. In cases when participants in the Constitutional judgment are state organs, they are represented by their executives and in their absence, by persons authorized in written form.

3. Representatives of the participants in the Constitutional judgment may be lawyers, who are equipped with the power attorney or designated as such by declaration in plenary.

4. National Bar Association designates the list of lawyers who may participate in the representation of cases in the Constitutional Court.

From the content of this provision we realize as participants in the Constitutional process, the applicant who is considered the party who submitted the request, while interested subjects are entities against whom is submitted the request, entities that have a direct interest in the matter being examinee, the body that issued the act and state bodies that are in disagreement about their competencies. While the points 2, 3 and 4 of this provision regulate the problem of participants' representation in the Constitutional Court. Furthermore is continued to a more detailed analysis for each of these participants.

\section{Applicant}

Article 28 and 39 of $\mathrm{CCL}$ is limited only in determining the "applicant" party, as a subject who has submitted an application to the Constitutional Court to set it in motion and all procedural mechanism. In fact these are two referral

\footnotetext{
${ }^{1}$ Law On organizing and functioning of the Constitutional Court of Albania (CCL)
} 
provisions, primarily to refer to the country's fundamental law, in the Constitution, which defines the entities that have legal capacity to initiate a constitutional process.

Such entities are defined in Article 134 of the Constitution, as follows: a) the President; $b$ ) the Prime Minister; c) not less than one fifth of the deputies; d) The President of the Supreme Audit Office; d) any court; f) The Ombudsman; e) local government; $h$ ) organs of religious communities; f) Political parties and other organizations; $g$ ) individuals.

In addition to these subjects, in the Constitution for certain categories of constitutional judgment we also find other subjects as for instance: the Parliament in cases of impeachment proceedings against the President, the Constitutional Court and Supreme Court judges, judgments on the incompatibility of the mandate of the deputies and the President etc. Another subject mentioned in the Constitution is the Council of Ministers in the case of control of compliance with the Constitution of international agreements ratified before the entry into force of this Constitution. Likewise another subject is also the Attorney General, which propel the Constitutional Court to assess cases of arrest in flagrante of Constitutional Court and High Court judges.

Legal capacity of these entities to put the Constitutional Court in motion is being determined by the fact that they are provided as such by the Constitution, so they have a constitutional legal personality. However, the Constitution itself contains expressed or implied criteria on the basis of which these entities can implement the Constitutional Court. Thus, the Parliament, the Council of Ministers and the Attorney General are conditioned subjects. They can put the Constitutional Court in motion only in cases and trials strictly defined in the Constitution.

In terms of subjects provided under Article 134 of the Constitution, they can be divided into several categories. The first category are unconditional subjects, ie, entities for which is not necessary the verification of the existence of interest in the matter under consideration (Zaganjori, Anastasi, Çani, 2011). The Constitution has recognized that the interest of public office holders that is being granted to the President, Prime Minister, one fifth of the deputies and the Chairman of the High State Control, in order to protect the normative system and state constituent principles as constitutionalism, the rule of law , democracy, human dignity, social equality, etc., can not be conditioned (Sadushi, 2012).

These subjects have unconditional legitimacy to all sorts of constitutional adjudication which has abstract nature, as the final interpretation of the constitution, the control of the constitutionality of laws, the normative acts of central and local government, as well as controlling the compliance of international agreements with the Constitution. In general, constitutional jurisprudence has been consequent in terms of unconditional legitimacy of these subjects. Therefore it was never emerged the problem of legitimacy the President, whenever he was invested in a constitutional trial (Constitutional Court, 1998, 2000, 2002, 2005). The court has held the same attitude in the Prime Miniter case as a constitutional entity (Constitutional Court, 2002). Regarding one fifth of the deputies, as a constitutional subject able to initiate such a process, the Constitutional Court as a rule has held the same position emphasizing that this subject is considered as unconditional and therefore it is not necessary to justify his interest (Constitutional Court, 2008). However in practice is shown a case where the subject is not legitimate to look for the abstract control of the law, (Constitutional Court, 2012) justifying this fact with the interes this subject need to have. Nevertheless, such a case taken by a relative majority of the judges does not establish a precedent in constitutional jurisprudence and remains an isolated case (Constitutional Court, 2014).

Regarding the Chairman of the High State Control, although as a subject has not been very active for puting into motion the Constitutional Court, its legitimizing as unconditional subject is never put into question (Constitutional Court, 2001, 2007).

Despite the opinion that exists in the doctrine that regarding the unconditional subjects they can put in motion the Constitutional Court on all cases included in its jurisdiction (Abdiu, 2000, Sadushi 2012), also signifying concrete judgments, personally in my opinion these subjects are always legitimate to put the Constitutional Court in motion, only for the abstract judgments. Thus each of these subjects have to justify its interest in case of disputes judgments of competencies and can not defend the interests or competencies of other constitutional bodies (Constitutional Court, $2009,2011)$. The same can be said for constitutional judgment to a fair trial. In these cases is understandable that these subjects may be party to such a judgment only if according to the procedures they have had procedural quality of party in trials conducted at the ordinary judiciary at all its levels. Otherwise they can not be initiated to put in motion such a judgment (Vorpsi, 2011).

The second category of subjects are those entities provided from letter "dh" to the letter "f" of Article 134 of the Constitution and respectively Ombudsman; local government bodies; organs of religious communities; political parties and other organizations.

These subjects based on article 134, point 2 of the Constitution, in order to put the Costitutional Court in motion are obliged to justify their interest in the given case (Zaganjori, Anastasi, Çani, 2011). In this case, the interest as an element of the application presents special study importance because its existence or not stipulate the completeness of the 
application as well as constitutes the main precondition in assessing the legitimacy (Pirdeni, 2011). Traditionally in the doctrine, by interest we understand, latu sensu, a consideration of moral or economic character that an issue or process belongs to a person or matters to him, attracts, worries or violates the person in question. While, strictu sensu, the interest to claim a file is causa petendi, hence the reason of the application. Interest will be considered as the primary precondition which determines the legitimacy ratione materiae of the subject forced to justify it before the Constitutional Court (Pirdeni 2011). So, the interest relates to subjects' access to seek or restore through the Constitutional Court the recognition of a right guaranteed by the Constitution and that results denied or violated by the concrete norm (Sadushi 2012).

Interest is not taken for granted, but rather the applicant has the burden of proof to prove the interest in the concrete case. From the above can be affirmed that is not sufficient from the applicant to prove that the claimed unconstitutional provisions is applicable to him, but he must prove that it affects him, causing adverse consequences that violates himself or his functions unfavorably, or in other words it risks to harm him or the interests he represents (Pirdeni, 2011).

Interest in the constitutional sense has the following characteristics:

a) Interest should be legal, therefore it should be legally protected and in case of a claim before the Constitutional Court the interest must submit importance by the constitutional point of view thus must be linked to a particular constitutional provision or an international agreement as appropriate.

b) Interest should be direct therefore must be a direct link between the constitutional right that subject claims to have been violated and constitutional control on the other side.

c) Interest should be personal, therefore the alleged act as unconstitutional should affect the applicant and its interests in an individualized way. In other words the right to request is being recognized only to him who is the holder of a constitutional right which is claimed denied or impaired. The court is not set in motion at the request submitted by a person who invokes a violation of the constitutional rights of another entity (Pirdeni, 2011).

If we see individually the subjects, we note that Ombudsman, despite fluctuations that appeared initially in the constitutional jurisprudence limiting its legitimacy only to normative bylaws (Constitutional Court, 2001, 2004), it turns out that today, the object of contradiction to the Constitutional Court may be laws (Constitutional Court, 2007, 2010).

But herein should be noted that the Ombudsman may oppose the legal acts and bylaws in the Constitutional Court only for constitutional material rights of subjects who complain to him. It is not in his interest controlling the legal acts and bylaws from the formal point of view or defending the independence of other constitutional bodies.

The same applies also with the local government. According to the Constitution, with the term body must be understood the executive body 9Constitutional Court, 1999) as well as the representative body, Constitutional Court, 2009). Therefore, both these bodies independently of each other have the right to set in motion the Constitutional Court on cases pertaining to the organization, operation, decentralization and local autonomy as they have justified and proven before the Court, their interest in the relevant case.

As regards the religious communities bodies, should be admitted that to date has not been cases where the Court was put in motion by such entities. A subject in order to be considered as a religious community should refer to Article 10 , point 5 of the Constitution of the Republic of Albania, thus, religious community are only the entities that have entered into an agreement with the Council of Ministers and afterwards ratified in Parliament. These entities may address to the Constitutional Court only on matters of religion, for violation of their internal organization, given that religious agreements are considered on the same level with ratified international agreements, as well as for their violation.

Another constitutional subject are political parties. These entities can set in motion the Constitutional Court on cases affecting their constitutional role as central factors of forming voters' political will (Constitutional Court, 2005, 2010, 2012) as well as for issues that interfere in their internal organization. In this sense, the political parties are not legitimate to file an application before the Constitutional Court on issues related to the interests of their members or sympathizers (Constitutional Court, 2011) given that these interests are multifaceted and general then this kind of legitimation would give them virtually the role of an uncondition subject. However, the Constitutional Court in its practice has legitimized a political party to oppose the constitutionality of an international agreement prior to its ratification by the Parliament. But in this case its legitimation was justified by the weight this party had in the Parliament as a result of the number of deputies that had won parliamentary elections (Constitutional Court, 2010).

The last subject of this category are other organizations. In the Constitution of the Republic of Albania the term "organization" is mentioned in several connotations, in literal-grammatical analysis results that Constitumaker with organization, in the general sense, has perceived those political (Article 131, letter "d"), ethnic cultural, religious, linguistic (Article 20, point 2), trade union (Article 50), social, economic, commercial (Article 61, point 4) and others (Article 9, point 
2).

So, the Constitution has left open the meaning to be given to the term "organization" for groupings with other purposes of organizing individuals (Albanian citizens or foreigners), provided that their organization complies with democratic principles, while their programs and activities should not based on totalitarian methods, which incite and support racial, religious, regional or ethnic hatred, who use violence to take power or influence state policy and not to be with secret character (Article 9, point 2 of the Constitution) (Constitutional Court, 2008). The Court has expressed that the assessment whether or not an organization has sufficient interest, is done case by case, depending on the circumstances of each particular case. Organization that set in motion the Court must prove that in what way it can be affected in one aspect of its operations, thus must prove a direct and individualized link that exists between its activity and norm opposes. The interest to operate should be safe, direct and personal. This interest consists in the right violated, at the real or potential damage and not the theoretical premises on the unconstitutionality of the norm that has brought this violation of interest. The fact that the contested provisions may have or have had any effect on the applicant is not sufficient to determine whether is legitimated to submit the request, but is necessary to prove that the challenged provisions regulates relationships that are the goal of the activity of the applicant, as defined in the Constitution, laws, or in the case of subjects of private law, in the statute (Constitutional Court, 2008, 2010, 2011).

Nevertheless, the Constitutional Court recently declared that the organization in order to have legal capacity to put in motion the Constitutional Court must be an open membership organization. Organizations without an open membership are excluded from the opportunity to initiate a constitutional process (Constitutional Court, 2013). It is worth emphazising that this position of the Constitutional Court contradicts its earlier decisionmaking (Constitutional Court 2008).

Besides the two above categories, Article 134 of the Constitution mention two other subjects: the courts and individuals. In relation to the courts, Article 134 of the Constitution is a reference provision which refers to Article 145, point 2 of the Constitution. Relying on this provision and Article 68 of $\mathrm{CCL}$ results that the courts, can put in motion the Constitutional Court only to opppose the legal provisions related directly to the issue under consideration before them (Zaganjori, Anastasi, Çani, 2011). While for individuals, it turns out that their stated interest is defined by the Constitution itself, specifically Article 131, letter "f", indicated that individuals can initiate a constitutional process only if they profess violations of their right to a fair trial and only after they have exhausted all other legal remedies available (Vorpsi, 2011).

In relation to the applicant, CCL shall follow another technique. Thus, for any particular trial it cares to provide the requesting entities themselves, sometimes by going even further the constitutional provisions.

\section{Interested Parties}

Article 28 of CCL and the constitutional jurisprudence considers other entities that have no procedural position of the applicant as interested entities. Article 39 of $\mathrm{CCL}$ classifies these subjects as a) entities against whom the application is being submitted; b) entities that have a direct interest in the matter being considered, $c$ ) the body that issued the act and c) state organs who are in competence dissagrement.

As a rule, the procedural position of these entities is being defined early in the application submitted by the applicant where among other things he has an obligation to determine the subject interested in this issue. Another possibility is that these entities are called by the court on its own initiative, an accepted fact on its jurisprudence (Constitutional Court, 2009). In this case it has full discretion to decide on the subjects that could investigate in a constitutional judgment. Such a right the court expressly has recognized itself even in its internal regulation leaving this decision, depending on the procedural situation, to the College or to the Meeting of Judges of the Constitutional Court (Regulation of the Constitutional Court, articles 6, point 2 and 8, point 2). In my opinion, this right of the court to call these people find support in Article 193 of the Civil Procedure Code, a provision which provides that:

The Court when considers that a trial should take place in the presence of a third person, who turns out to have an interest in the case, appeals him and therefore postpone the hearing.

Secretary notifies him with the invitation.

Based on this formulation, which in the case of constitutional judgment is being implemented mutatis mutandis and in Article 1, point 2 of CCL that allows the implementation of other procedural laws, then the right of the Constitutional Court to appeal other subjects beyond those specified by the parties finds full legal support. Moreover, referring to this provision, regardless of the regulation that does not specify the appeal of the interested subject by the court in a plenary session, in my opinion the appeal of such an entity can be made even at this stage of the judgment, with an interim 
decision, if during the judicial review is shown needed such a procedural action.

Another possibility for legitimating an interested subject is that he seeks to take part in the constitutional process itself, presenting before the court relevant arguments and evidences in support of his application (Constitutional Court, 2011, 2012). Such request can be made at any stage of constitutional process.

While maintaining the same order specified by the law, below are further analyzed these subjects under relevant categories:

a) subjects against whom is submitted the application; as a rule, these entities are included in concrete trials held before the Constitutional Court. Thus, in case of proceedings held before this Court to review the constitutionality of parties and other political organizations, such a subject is a party/political organization which is required to be declared unconstitutional (Constitutional Court, 2013). Another subject that is included in this category is the President of the Republic on the occasion of his dismissal procedures, verification of the impossibility of exercising his functions, or in other cases of trials to ascertain its compliance function or the control for his election. Deputy is also another subject who is included in this category in the cases of trials for eligibility or incompatibility of functions (Constitutional Court, 2011). The last subjects that can be mention in this case, are various private parties in the case of trials for a fair hearing. These are subjects who have won judgments in other scales of the judiciary system and which the trial loser opposes through a constitutional judgment. In these cases, these entities are called in order to give their arguments on the claims of the requesting party (Vorpsi, 2011).

b) subjects that have a direct interest in the matter being considered.

These are subjects who may be called at any constitutional process that takes place, is sufficient to justify the fact that they have an interest in resolving the case before the Constitutional Court. In trials for final interpretation of a constitutional norm, CCL determines that in this case is called the body that pretend to have wrongly interpreted the Constitution. While from the point of view of the Constitutional Court's jurisprudence regarding this trial results that are also called other entities whose interests may be affected by the interpretation that can give the Constitutional Court (Constitutional Court, 2002, 2013). In trials on laws, turns out that as a rule are always called even the entity which has proposed the law in Parliament. The same reasoning can be followed for other trials as well, taking in evaluation the position of this category of entities case by case.

Likewise the proposing subjects of a law or legal act if they are not called as such by the applicant or by the court are entitled to make a request by their own at the Constitutional Court seeking to intervene in the process (Constitutional Court, 2011).

In this category are included even subjects who does not only have an interest in the case being considered by the court but on the other side they may contribute in the decision of the Constitutional Court therefore their call presents interest and necessity for the constitutional judgment. Calling these entities is at the discretion of the court itself which decides case by case on their appealing and legitimism, depending on the nature of the case (Constitutional Court, 2009).

Are not included in this category and therefore cannot apply the subjects who defend their interests in a constitutional trial which for the type and nature is different from the constitutional trial that is taking place (Constitutional Court 2012, 2015).

c) the body that has issued the act, is another subject whose calling is mandatory in constitutional judgments. Thus, in the judgment of the law, should be called the Parliament, while in trials for normative acts are called respectively the body that issued the act, it may be the Council of Ministers (Constitutional Court, 2014) or the ministry (Constitutional Court, 2013), depending on the act which is the subject of the trial. Also, are called the local authorities (the mayor or the council) in cases where the subject of judgment in the Constitutional Court is their issued normative act.

The only exceptional case is in the constitutional judgment of the legal hearing where despite the fact that judgment objects are the decisions taken by the ordinary courts, these courts are not part of the constitutional process (Vorpsi, 2011). Therefore it turns out that the term "act" in this case represents a legal act or a sublegal act with normative character.

d) State bodies that are in disagreement about competencies. This point of Article 39 of CCL includes essentially a wider circle of subjects. State authorities in this case have the quality of applicants as well as the quality of the subject concerned. It is worth mentioning that Article 54 of CCL provides that the Constitutional Court in this case is set in motion by the entities in conflict or entities directly affected by the conflict. This means that is recognized in the jurisprudence of the Constitutional Court that the dispute of competence may arise: 
Firstly: with all constitutional bodies

Secondly: between the bodies or entities that do not participate in a determined manner, in this or that power, such as the prosecutor on one hand and the Parliament on the other.

Thirdly: between the constitutional body from one side and a part of the constitutional body on the other, i.e. not less than a quarter of parliament deputies (Sadushi, 2012, Constitutional Court, 2006, 2007, 2008).

As a matter of fact, Constitution mentions several organs, which doctrine and jurisprudence (Constitutional Court, 2008) have classified into three categories:

1. Constitutional bodies. These are structures which serve to the functioning of the state and are essential to its existence. This category includes bodies such as the Parliament, the President, the Council of Ministers, the Judicial Power, the Local Governance.

2. Institutions envisaged by the Constitution. These are institutions that serve to the functioning of constitutional bodies and are ancillary to them. The condition of their existence is the fact that the constitution should recognize to them legal personality as well as to provide them with powers expressly provided.

3. Bodies mentioned in the Constitution. These are bodies that are mentioned in the Constitution as a result of the competence that constitutional bodies have to designate the heads of these institutions but can not be classified in two categories because the Constitution does not recognize to them legal personality and does not provide any authority to them.

In reference to the conclusions drawn from the case law, we can conclude that the only bodies/institutions provided in the first two categories may be subjects to a trial for resolving the disputes of competencies, as they are the only bodies endowed with constitutional powers. The competencies of other bodies, which are regulated by law, under no circumstances may not be legitimated, because the dissagreements between them are solved by the ordinary courts. On the other side, interested entities will be those bodies from the first two categories which with their action or non action have violated the constitutional competence of the requesting organ.

From this analysis results that the subjects to put in motion the Constitutional Court for adjudication of a competence dissagreament are not only those provided by Article 134 of the Constitution.

\section{Conclusions}

As it was set out in this article, the procedural position of the parties in a constitutional trial is of a fundamental importance. So the right definition of the suitor interest in relation to the required constitutional judgment takes a special importance. In this way, although it is always claimed by the legal doctrine in Albania that unconditional entities may invents the Constitutional Court, for any process, the jurisprudence of this Court shows that such entities may invest the court only for trials of an abstract sort such as the final interpretation of the Constitution, the compliance of laws, international agreements and normative acts with the Constitution. For other trials of a concrete sort, such as the dispute of competences or due legal process, it turns out that even these subjects may invest a constitutional trial, but only with the condition to justify their interest.

Regarding conditional subjects, the constitutional jurisprudence has always been consolidated according to which these entities have to justify their interest in that case, interest which is proved case by case according to requirements set by the Constitutional Court precedents. Furthermore in some types of trials, the definition of the suitor subject is provided by the Constitution, leaving no opportunity for the participation of other entities.

Another important aspect is the definition of interested parties who should take part in a constitutional judgment. The participation of these subjects is important in order to provide them the opportunity to protect their acts or activities, as well as to guarantee a due legal process even in the constitutional judgments.

\section{References}

Abdiu, Fehmi, "Kushtetuta dhe Gjykata Kushtetuese e Republikës së Shqipërisë", Shtëpia Botuese "Redona", Tiranë, 2001.

Vorpsi, Arta, "Procesi i rregullt ligjor në praktikën e Gjykatës Kushtetuese të Republikës së Shqipërisë", botim i Fondacionit "Konrad Adenauer Stiftung", Shtëpia Botuese "Maluka", Tiranë, 2011.

Zaganjori, Xhezair; Anastasi, Aurela ; Çani, Eralda (Methasani); "Shteti i së drejtës në Kushtetutën e Republikës së Shqipërisë”, Shtëpia Botuese "Adelprint", Tiranë, 2011.

Pirdeni, Adea, "Justifikimi i interesit në gjykimin kushtetues: Vështrim mbi praktikën e Gjykatës Kushtetuese të Republikës së Shqipërisë", botuar në Revistën "Studime Juridike", Nr.2/2011, Botim i Fakultetit të Drejtësisë të Universitetit të Tiranës, Shtëpia Botuese "Pegi", Tiranë 2011.

Sadushi, Sokol, "Drejtësia Kushtetuese në zhvillim", Shtëpia Botuese "Toena", Tiranë 2012. 


\section{Legal Text}

Law no.8577, date 10.02.2001 "On the organizations and function of the Constitutional Court of the Republic of Albania". Regulation of the Constitutional Court, 2009

\section{Decisions of the Albanian Constitutional Court}

Available from http://www.gjk.gov.al/web/Vendime_perfundimtare_100_1.php

\section{Decision of the Constitutional Court in plenary session}

Decision No.77, date 31.12.1998

Decision No.2, date 25.01.1999

Decision No.8 date 03.03.2000

Decision No.33, date 09.05.2001

Decision No.178, date 08.11.2001

Decision No. 6, date 18.01.2002

Decision No.75, date 19.4.2002

Decision No. 212, date 29.10.2002

Decision No.2, date 03.02.2004

Decision No. 1, date 07.01.2005

Decision No. 2, date 18.01.2005

Decision No.19, date 03.05.2007

Decision No.40, date 16.11.2007

Decision No.9, date 19.03.2008

Decision No.16, date 25.07.2008

Decision No.17, date 25.07.2008

Decision No.18, date 29.07.2008

Decision No.25, date 05.12.2008

Decision No.19, date 09.07.2009

Decision No.29, date 21.10.2009

Decision No.15, date 15.04.2010

Decision No.17, date 23.04.2010

Decision No.27, date 26.05.2010

Decision No.29, date 31.05.2010

Decision No.31, date 18.06.2010

Decision No.32, date 21.06.2010

Decision No.33, date 24.06.2010

Decision No.4, date 23.02.2011

Decision No.43, date 6.10.2011

Decision No.44, date 7.10.2011

Decision No.25, date 08.05.2012

Decision No.28, date 09.05.2012

Decision No.7, date 27.02.2013

Decision No.13, date 27.02.2013

Decision No.18, date 14.5.2013

Decision No.5, date 5.2.2014

Decision No.20, date 4.4.2014

Decision No.36, date 1.6.2015

\section{Decision of the Judges Meeting of the Constitutional Court}

Decision No. 113, date 13.10.2011

\section{Decision of the College of the Constitutional Court}

Decision No.101, date 25.09.2012

Decision No.31, date 26.02.2013 